\title{
Pembelajaran Keliling Lingkaran Menggunakan Konteks Gelas
}

\author{
N. Nurdiansyah ${ }^{\mathbf{1}}$, Rully Charitas Indra Prahmana ${ }^{2}$ * \\ ${ }^{1}$ SMA Negeri 1 Manggar, Jl. Jendral Sudirman, Mekar Jaya, Manggar, Belitung Timur, Bangka \\ Belitung 33512, Indonesia. \\ ${ }^{2}$ Universitas Ahmad Dahlan, J1. Pramuka Kav. 5, Pandeyan, Yogyakarta 55161, Indonesia \\ * Correponding Author. E-mail: rully.indra@mpmat.uad.ac.id, Telp. (+62274) 563515 \\ Received: 12 July 2017; Revised: 22 August 2017; Accepted: 11 October 2017
}

\begin{abstract}
Abstrak
Penelitian ini bertujuan untuk mengetahui peran konteks gelas dalam mendukung pembelajaran konsep keliling lingkaran dan mengetahui respon peserta didik terhadap pembelajaran matematika menggunakan pendekatan Realistic Mathematics Education (RME). Penelitian ini dilaksanakan di Sekolah Menengah Pertama (SMP) Surya Bangsa, Tangerang. Subjek penelitian ini adalah peserta didik kelas VIII.A Tahun Ajaran 2015/2016 semester II dengan jumlah peserta didik sebanyak 13 orang. Instrumen penelitian yang digunakan dalam penelitian ini terdiri atas Lembar Aktivitas Peserta Didik (LAPD), Soal Evaluasi, Lembar Observasi Guru, Panduan Wawancara dan Angket Respon Peserta Didik. Teknik pengumpulan data pada penelitian ini meliputi rekaman video, pengisian dokumen penelitian, observasi dan wawancara. Analisis data dilakukan menggunakan model Miles \& Huberman (1994) yang terdiri atas reduksi data, penyajian data, penyimpulan dan verifikasi. Pembelajaran dalam penelitian ini menggunakan konteks gelas berdasarkan karakteristik pendekatan RME. Hasil dari penelitian ini menunjukkan bahwa konteks gelas berperan penting dalam mendukung pembelajaran konsep keliling lingkaran. Selain itu, peserta didik memiliki respon yang positif terhadap pembelajaran matematika yang diberikan menggunakan pendekatan RME.
\end{abstract}

Kata Kunci: kualitatif deskriptif, konteks gelas, RME, keliling lingkaran

\section{Learning Circumference Using the Context of Glass}

\begin{abstract}
This research aims to find out the role of glass as a context in supporting the concepts of the circumference of the circle and to know the response of learners in learning mathematics using Realistic Mathematics Education (RME) approach. This research conducted at Surya Bangsa Junior High School, Tangerang. The subjects of this study are students of class VIII.A in the academic year 2015/2016 semester II with the number of learners as many as 13 people. The research instruments used in this study consist of Student Activity Sheet (SAS), Evaluation Test, Observation Sheet, Interview Guide, and Questionnaire. Data collection techniques in this study include video recording, completion of research documents, observation, and interviews. Data analysis technique using Miles \& Huberman (1994) model consisting of reduction data, presenting data, conclusion and verification. The learning in this study uses the context of glass based on the characteristics of the RME approach. The results of this study indicate that the context of glass plays a significant role in supporting learning the concept of the circumference of the circle. Also, learners have a positive response in learning mathematics provided using the RME approach.
\end{abstract}

Keywords: descriptive qualitative, the context of glass, RME, the circumference of the circle

How to Cite: Nurdiansyah, N., \& Prahmana, R. (2017). Pembelajaran keliling lingkaran menggunakan konteks gelas. Jurnal Riset Pendidikan Matematika, 4(2), 128-140. doi:http://dx.doi.org/10.21831/jrpm.v4i2.14829

Permalink/DOI: http://dx.doi.org/10.21831/jrpm.v4i2.14829 


\section{Jurnal Riset Pendidikan Matematika, 4 (2), 2017 - 129}

N. Nurdiansyah, Rully Charitas Indra Prahmana

\section{PENDAHULUAN}

Kesulitan peserta didik dalam memahami satu sub materi pelajaran sering menjadi penghambat dalam proses belajar mengajar pada materi selanjutnya (Prahmana, Zulkardi, \& Hartono, 2012). Salah satu penyebab dari hal tersebut ialah selama proses belajar mengajar kebanyakan guru masih menggunakan metode ceramah dan tanya jawab (Santosa, Budiyono, \& Subanti, 2014). Ini artinya proses pembelajaran masih berpusat pada guru dan peserta didik belum berperan aktif dalam belajar karena hanya sebatas tanya jawab. Selanjutnya, Ahmad, Usodo, \& Riyadi (2014) menyatakan bahwa pembelajaran yang cenderung berpusat dan bersumber dari guru tidak mengajarkan peserta didik untuk mengonstruksi pelajaran dan mengakibatkan siswa bersifat pasif. Oleh karena itu, diperlukan suatu cara pengajaran yang lebih terpusat kepada peserta didik agar peserta didik dapat mengonstruksi sendiri pelajaran yang diberikan oleh guru.

Berkaitan dengan pengajaran yang mengkonstruksi pengetahuan peserta didik, Freudenthal (Wijaya, 2012) menyatakan sebaiknya peserta didik tidak mendapatkan konsep dari suatu pelajaran secara langsung, akan tetapi melalui kegiatan mengkonstruksi konsep matematika. Selain itu, Prahmana (2010) menyatakan bahwa pengalaman peserta didik dalam kehidupan sehari-hari memiliki keterkaitan dengan konsep-konsep matematika. Oleh karena itu, perlunya suatu bentuk pembelajaran yang menggunakan pengalaman dalam kehidupan seharihari untuk mengkonstruksi konsep-konsep matematika.

Prahmana (2012) menyatakan bahwa terdapat beberapa pendekatan pembelajaran yang menggunakan konteks dunia nyata, salah satunya adalah pendekatan Realistic Mathematics Education (RME). Di sisi lain, dunia nyata dapat digunakan sebagai titik awal untuk pengembangan ide dan konsep matematika dalam pendekatan RME (Hadi, 2017). Pendekatan RME dikembangkan oleh Institut Freudenthal sejak tahun 1971 yang didirikan oleh Prof. Hans Freudenthal (Hadi, 2017). Van den Heuvel Panhuizen (Wijaya, 2012) menyatakan bahwa RME merupakan suatu pendekatan pembelajaran matematika yang tidak sekedar menunjukkan adanya suatu koneksi dengan dunia nyata, tetapi lebih mengacu pada fokus dalam menempatkan penekanan penggunaan suatu situasi yang bisa dibayangkan oleh siswa.
Selain itu, pendekatan RME memiliki karakteristik yang dapat digunakan sebagai panduan dalam pembelajaran. Oleh karena itu, peneliti menggunakan pendekatan RME sebagai pendekatan yang akan digunakan untuk menyampaikan pembelajaran kepada peserta didik.

Sejumlah peneliti telah mendokumentasikan hasil penelitiannya terkait penggunakan pendekatan RME (Hernawati, 2016; Sari, 2016; Wibowo, 2017) menyatakan bahwa pendekatan RME memberikan pengaruh yang lebih efektif dibandingkan dengan pembelajaran konvensional terhadap prestasi belajar, kemampuan penalaran matematis, dan minat belajar. Oleh karena itu, pendekatan ini memberikan hasil yang baik dalam proses pembelajaran matematika di kelas.

Selain menggunakan pendekatan yang tepat, pelaksanaan pembelajaran juga tidak terlepas dari kurikulum. Permendiknas Nomor 22 Tahun 2006 menyatakan bahwa, salah satu prinsip pelaksanaan kurikulum adalah kurikulum dilaksanakan dengan pendekatan multistrategi dan multimedia, sumber belajar dan teknologi yang memadai, dan memanfaatkan lingkungan sekitar sebagai sumber belajar, dengan prinsip alam takambang jadi guru (semua yang terjadi, tergelar, dan berkembang di lingkungan masyarakat dan lingkungan sekitar serta lingkungan alam semesta dijadikan sumber belajar, contoh dan teladan) (Menteri Pendidikan Nasional Republik Indonesia, 2006). Prinsip tersebut sejalan dengan pendekatan RME, guru dapat menggunakan sesuatu yang ada di lingkungan sekitar sebagai sumber belajar (Gravemeijer, 1994). Salah satu contoh benda yang ada di lingkungan sekitar kita yang bisa digunakan untuk belajar adalah gelas. Bibir gelas yang pada umumnya berbentuk lingkaran dapat digunakan sebagai konteks dalam pembelajaran materi lingkaran.

Lingkaran merupakan salah satu materi pada pelajaran matematika yang diajarkan pada peserta didik kelas VIII SMP. Materi lingkaran banyak bermanfaat dalam kehidupan sehari-hari, seperti halnya dalam membangun gedung yang berbentuk lingkaran, membuat roda mobil, membuat gelas dengan bibir berbentuk lingkaran, dan masih banyak benda lain yang mengandung unsur lingkaran (Emilya, Darmawijoyo, \& Ilma, 2010). Oleh karena itu, dari berbagai manfaat pembelajaran tersebut, alangkah baiknya apabila pembelajaran tentang lingkaran dapat menggunakan konteks nyata pada kehidupan sehari-hari. 
Pada proses pembelajarannya, pendekatan RME merupakan suatu pendekatan yang di dalamnya terdapat penggunaan konteks pembelajaran (Gravemeijer, 1994). Oleh karena itu, peneliti tertarik melakukan penelitian tentang penggunaan konteks gelas pada pembelajaran keliling lingkaran menggunakan konteks gelas, yang bertujuan untuk mengetahui peranan konteks gelas dalam mendukung pembelajaran konsep keliling lingkaran dan respon siswa terhadap pembelajaran tersebut menggunakan pendekatan RME.

\section{METODE}

Metode yang digunakan peneliti dalam penelitian ini adalah metode penelitian kualitatif deskriptif. Sebagai subjek penelitian ini adalah 13 peserta didik kelas VIII.A Sekolah Menengah Pertama (SMP) Surya Bangsa Kota Tangerang. Penelitian dilaksanakan pada semester genap tahun ajaran 2015/2016. Penelitian dilaksanakan selama empat pertemuan yang terdiri atas 3 pertemuan digunakan untuk pembelajaran dengan pendekatan Realistic Mathematics Education (RME) dan 1 pertemuan digunakan untuk pengisian lembar evaluasi dan angket respon peserta didik. Untuk memaksimalkan data yang diperoleh, peneliti juga menggunakan instrumen tes dan non tes.

Instrumen tes pada penelitian ini adalah tes kognitif. Tes tersebut berupa 5 buah soal uraian yang dibuat berdasarkan ranah kognirif $\mathrm{C} 1, \mathrm{C} 2$, dan $\mathrm{C} 3$ dengan tujuan untuk mengetahui kemampuan kognitif peserta didik. Untuk mendapatkan data kemampuan tersebut, soal tes dibagikan dan diselesaikan oleh peserta didik pada akhir pertemuan penelitian.

Instrumen non tes terdiri atas angket respon peserta didik, lembar observasi pembelajaran,dan panduan wawancara. Untuk menganalisis hasil angket menggunakan skala Likert. Hasil angket yang diperoleh peserta didik diberikan skor dan dihitung persentase keseluruhan tiap pernyataan dan rata-rata dari setiap pernyataan yang memiliki indikator sama. Penelitian ini juga menggunakan lembar observasi pembelajaran untuk melihat apakah pembelajaran yang dilakukan oleh peneliti sesuai dengan rencana pembelajaran. Lembar observasi pembelajaran dibuat berdasarkan Rencana Pelaksanaan Pembelajaran (RPP) dan diisi oleh observer pada saat penelitian. Setiap pertemuan memiliki lembar observasi pembelajaran yang berbeda-beda.
Panduan wawancara berisikan beberapa pertanyaan terkait dengan pembelajaran yang dilakukan pada tiap pertemuan. Panduan wawancara dibuat sebagai acuan yang akan digunakan oleh peneliti untuk melakukan wawancara kepada peserta didik. Wawancara dilakukan setelah pembelajaran dilaksanakan. Panduan wawancara pada penelitian ini dibuat berdasarkan rumusan masalah penelitian.

Teknik pengumpulan data yang digunakan pada penelitian ini terdiri atas rekaman video yang dilakukan untuk merekam semua kejadian pada saat pembelajaran. Kemudian juga dilakukan pengisian dokumen hasil kerja peserta didik terdiri atas Lembar Kerja Peserta Didik (LKPD), Lembar Aktivitas Peserta Didik (LAPD) dan Angket Respon Peserta Didik. Observasi dilakukan dengan menggunakan lembar observasi yang terdiri atas lembar observasi peserta didik dan guru. Wawancara akan dilakukan kepada peserta didik terkait dengan pembelajaran yang telah dilakukan. Pada penelitian ini akan menggunakan teknik wawancara tak terstruktur.

Teknik analisis data yang digunakan pada penelitian ini adalah teknik analisis data Miles dan Huberman (1994), yang terdiri atas tiga tahapan yang saling berkaitan, yaitu reduksi data, penyajian data, dan penarikan kesimpulan. Pada tahap reduksi merupakan tahap pemilihan, fokus, menyederhanakan, abstrak, dan transformasi data yang diperoleh selama penelitian. Moleong (2013) menyatakan bahwa tahap reduksi data terdiri atas dua aktivitas, yaitu identifikasi dan koding. Identifikasi dilakukan untuk menemukan satuan atau bagian terkecil dari data yang diperoleh yang memiliki makna apabila dikaitkan dengan fokus dan masalah penelitian. Selanjutnya, membuat koding merupakan kegiatan pemberian kode atau nama pada satuan yang telah diidentifikasi.

Pada tahapan penyajian data, peneliti menyajikan data temuan penelitian dalam kategori atau kelompok. Penyajian data dapat dilakukan dalam bentuk matriks dan diagram. Untuk data wawancara dan video, penyajian data dilakukan dengan mentranskrip data tersebut ke dalam bentuk tulisan.

Tahap penarikan kesimpulan/verifikasi merupakan tahapan yang dilakukan peneliti dalam menarik kesimpulan dari temuan data penelitian. Selanjutnya setelah peneliti menarik kesimpulan, peneliti mengecek ulang proses pada tahap reduksi dan penyajian data untuk memastikan kesahihan dari kesimpulan yang 
diambil. Pada tahapan ini, dalam proses penarikan kesimpulan terdapat proses validitas data dengan menggunakan triangulasi data.

\section{HASIL DAN PEMBAHASAN}

\section{Pengukuran Bibir Gelas (Pertemuan I)}

Proses penentuan konteks dilakukan sesuai dengan salah satu prinsip dari pendekatan Realistic Mathematic Education (RME) yaitu guided reinvention and didactical phenomenology. Berdasarkan prinsip tersebut, peneliti hanya membimbing peserta didik untuk menemukan konsep dalam pembelajaran. Kegiatan yang dilakukan peneliti untuk mendapatkan tujuan tersebut adalah dengan menampilkan slide yang berisikan beberapa benda yang berbentuk lingkaran. Gambar-gambar yang ditampilkan dalam adalah drum minyak, roda mobil, galon air dan gelas. Sambil menampilkan gambar-gambar tersebut, peneliti juga melakukan diskusi berikut dengan peserta didik.

Guru : Coba perhatikan, ini gambar apa? (Gambar pertama)

Siswa : Tong

Guru : Ya, jika kita lihat permukaan atas atau bawahnya itu berbentuk apa?

Siswa : Lingkaran.

Guru : Ya, lingkaran.

Guru : Sekarang coba lihat gambar apa ini? (Gambar kedua)

Siswa : Mobil, pak

Guru : Kira-kira pada mobil tersebut ada tidak unsur-unsur lingkaran?

Siswa : Ada pak, Rodanya, logonya juga, stirnya juga berbentuk lingkaran.

Guru : Nah, kalau yang ini gambar apa? (gambar ketiga)

Siswa : Galon

Guru : Iya, setiap rumah pasti ada yang ini kan?

Siswa : Ada, pak.

Guru : Ada tidak yang berbentuk lingkaran pada gambar tersebut?

Siswa : Ada, pak... tutupnya, alasnya juga.

Guru : Iya, jadi kalau kita lihat dari atas, tutupnya berbentuk lingkaran.

Guru : Nah... kalau yang ini gambar apa? (Gambar keempat)

Siswa 1 : Gelas

Siswa 2 : Tempat Sampah

Siswa 1 : Gelas Bray, masa tempat sampah ada di atas laptop?

Guru : Iya, itu adalah gambar gelas, ada tidak yang berbentuk lingkaran pada gelas tersebut?

Siswa : Ada...

Dengan menampilkan gambar-gambar tersebut dan diskusi yang telah dilakukan, peser- ta didik memilih gelas sebagai konteks pembelajaran yang digunakan dalam pembelajaran keliling lingkaran. Setelah diskusi tentang satu persatu gambar yang ditampilkan, peneliti mengarahkan peserta didik dalam memilih konteks pembelajaran yang digunakan melalui diskusi berikut:

Guru : Dari gambar-gambar tersebut, benda manakah yang lebih mudah digunakan untuk pembelajaran tentang lingkaran?

Siswa : Gelas/ban mobil/galon air

Guru : Misalkan ban mobil, apakah mungkin kita bawa ban mobil ke kelas digunakan untuk belajar?

Siswa : Tidak, pak.

Guru : Misalkan galon air, memang kita lebih mudah untuk menemukannya. Setiap rumah kalian pasti memilikinya. Tetapi apakah ada benda yang lebih mudah dari galon berdasarkan gambar-gambar yang ada pada tersebut?

Siswa : Ada, pak... gelas

Guru : Jadi, sepakat semuanya kita menggunakan gelas?

Siswa : Kalau aku yes.

Berdasarkan dialog tersebut terdapat tiga jawaban yang dipilih oleh peserta didik, yaitu gelas, galon, dan roda mobil. Menanggapi jawaban tersebut, peneliti meluruskan pilihan peserta didik tersebut dengan memberikan pandangan bahwa betapa sulitnya jika kita harus membawa galon air, roda mobil ataupun drum minyak ke dalam kelas untuk belajar. Dengan demikian, disepakati bahwa konteks pembelajaran adalah gelas. Kemudian pembelajaran dilanjutkan dengan membimbing peserta didik untuk menyebutkan pembelajaran yang dilakukan melalui diskusi berikut:

Guru : Jika ada seekor semut berjalan mengitari bibir gelas dari tempat awal semut itu berjalan hingga kembali lagi ke tempat semula, proses apakah yang dilakukan oleh semut tersebut?

Siswa : Proses yang dilakukan oleh semut adalah mengelilingi bibir gelas.

Dari dialog tersebut, tanggapan dari peserta didik langsung mengarah kepada keliling lingkaran. Berdasarkan hal tersebut, peneliti menyampaikan bahwa pembelajaran yang akan dipelajari adalah keliling lingkaran. Peserta didik diminta untuk berdiskusi dengan teman di kelompoknya untuk menemukan cara mengukur keliling dan diameter bibir gelas dan menuliskan hasil yang diperoleh pada kolom yang telah disediakan pada lembar aktivitas yang telah disediakan. Secara keseluruhan peserta didik 
Jurnal Riset Pendidikan Matematika, 4 (2), 2017 - 132

N. Nurdiansyah, Rully Charitas Indra Prahmana

melakukan pengukuran dengan melilitkan meteran pada bibir gelas. Setelah terlilitkan dilihat ujung meteran. Proses pengukuran dapat dengan baik, untuk mengetahui ukurannya dilihat seperti tampak pada Gambar 1.

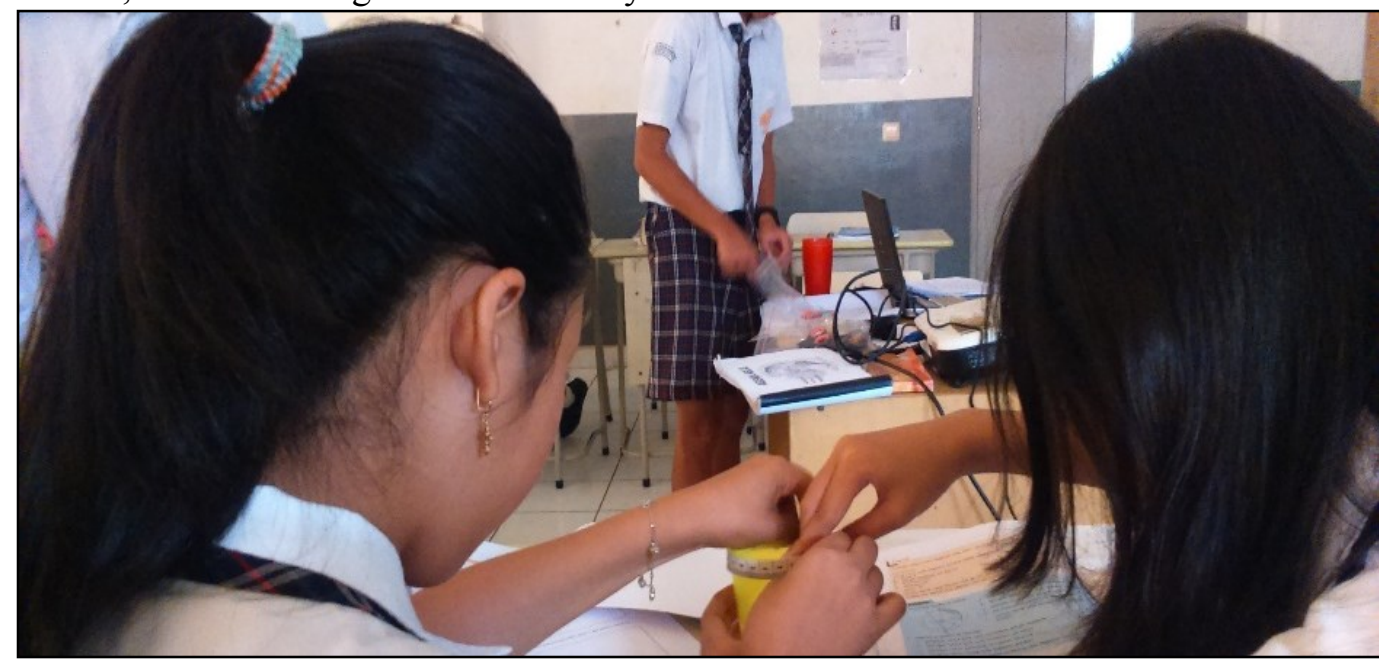

Gambar 1. Pengukuran Keliling Bibir Gelas dengan Meteran
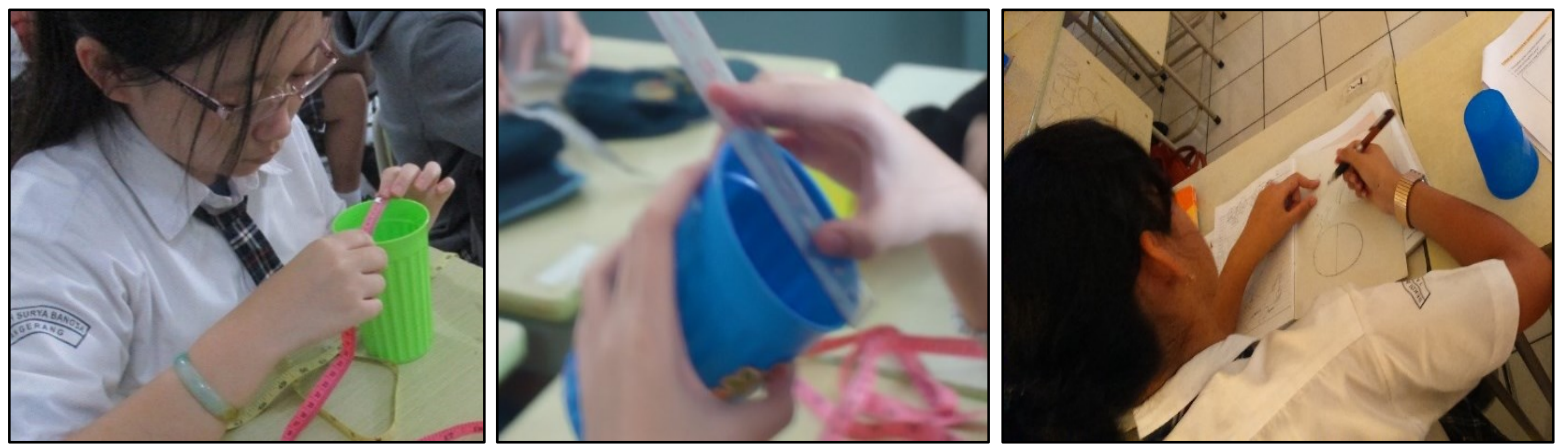

Gambar 2. Aktivitas Pengukuran Bibir Gelas dengan Berbagai Alat Ukur

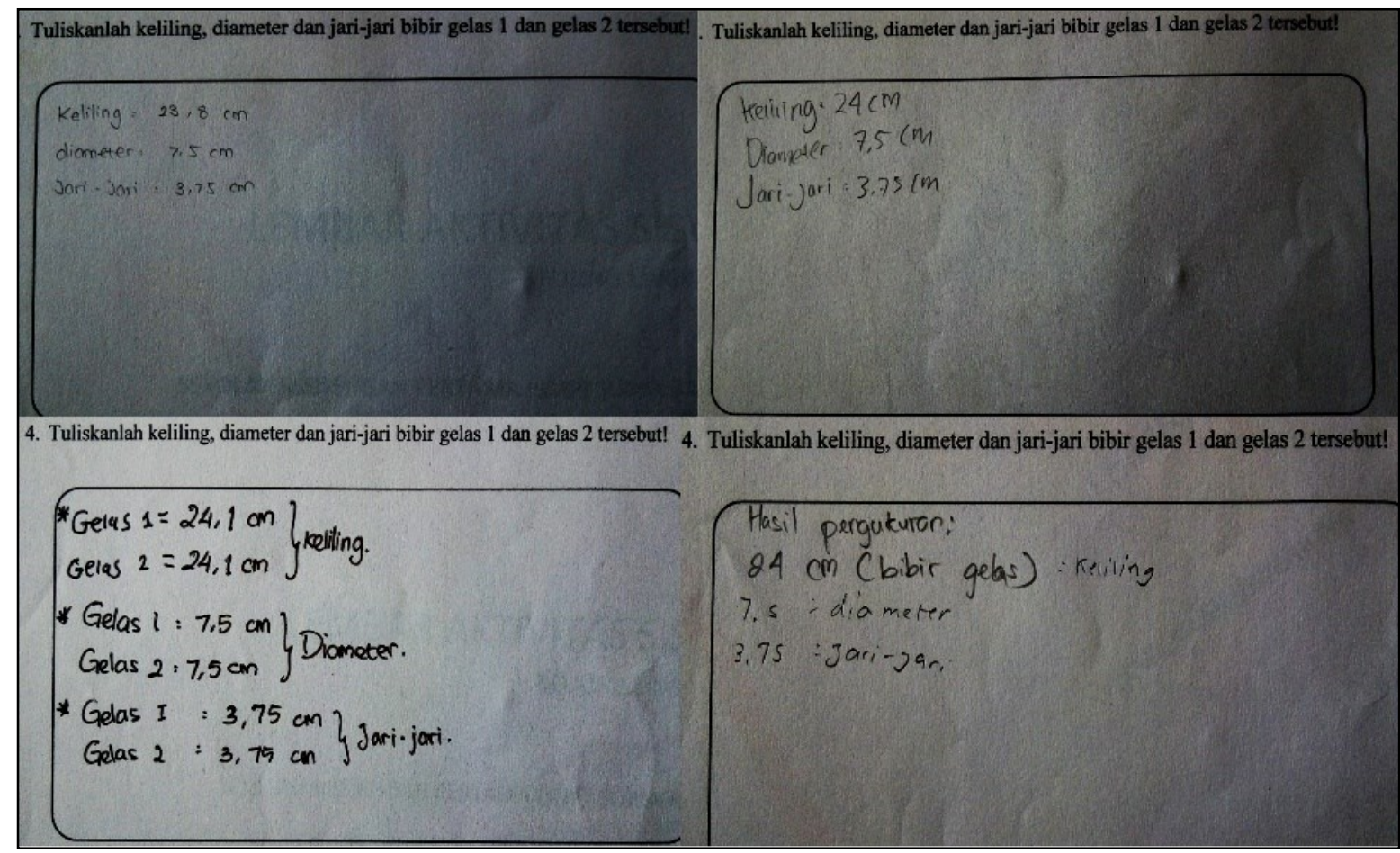

Gambar 3. Hasil Pengukuran Keliling dan Diameter Bibir Gelas 
Selain pengukuran keliling bibir gelas, dilakukan juga pengukuran diameternya. Pada pengukuran diameter terdapat beberapa cara yang dilakukan oleh peserta didik. Adapun cara yang dilakukan, yaitu menggunakan meteran, penggaris, dan melukiskan bibir gelas. Pengukuran dengan menggunakan meteran dilakukan dengan membentangkan meteran di atas bibir gelas. Kemudian dilihat jarak terpanjang yang diperoleh dalam pengukuran tersebut. Penggunaan penggaris pada pengukuran diameter bibir gelas dengan cara menempelkan penggaris pada bibir gelas. Untuk mendapatkan ukuran diameternya, peserta didik mencari posisi penggaris kira-kira melewati tengah-tengah gelas. Selanjutnya diameter diperoleh dari ukuran yang terlihat pada penggaris. Pengukuran diameter dengan melukiskan pada kertas ini merupakan cara yang unik di antara yang lain. Salah satu peserta didik melakukannya di sampul bukunya. Setelah dilukiskan pada kertas tersebut, diameter lingkaran yang terbentuk dari bibir gelas diukur dengan menggunakan penggaris. Pada pembuatan garis yang dianggap peserta didik diameter ini, hanya dengan perkiraan bahwa garis tersebut melewati titik tengah lingkaran. Kegiatan pengukuran dapat dilihat pada Gambar 2.

Setelah melakukan pengukuran, hasil tersebut dituliskan oleh masing-masing kelompok peserta didik pada lembar aktivitas yang telah disediakan oleh peneliti. Pada pertemuan pertama ini dapat peserta didik dapat menentukan konteks pembelajaran yang digunakan untuk pembelajaran keliling lingkaran. Selain itu, peserta didik juga dapat menghitung keliling dan diameter bibir gelas, seperti tampak pada Gambar 3.

\section{Penentuan Nilai $p i(\pi)$ (Pertemuan II)}

Pada pertemuan ini setiap peserta didik membawa gelas dengan ukuran yang berbeda dengan teman sekelompoknya. Seluruh peserta didik melakukan pengukuran menggunakan meteran. Hasil dari pengukuran yang telah dilakukan kemudian dituliskan pada lembar aktivitas. Hasil pengukuran dituliskan berdasarkan inisial dari setiap gelas yang diukur, baik itu menggunakan angka maupun menggunakan nama masing-masing.

Hasil pengukuran setiap peserta didik dalam satu kelompok berbeda-beda, seperti tampak pada Gambar 4. Tentunya hal tersebut disebabkan oleh ukuran gelas yang berbeda. Kegiatan berikutnya adalah peserta didik melakukan perhitungan perbandingan keliling dengan dia- meter bibir gelas masing-masing berdasarkan ukuran yang mereka dapatkan. Setelah dilakukan perhitungan, peserta didik mendapatkan hasil perbandingan keliling dengan diameter bibir gelas yang merupakan nilai $\pi$. Hasil perhitungan yang didapatkan oleh peserta didik untuk permasalahan pertama yang diberikan dapat dilihat pada Gambar 5.

Setelah menyelesaikan permasalahan yang terdapat pada LAPD, salah satu kelompok mempresentasikan hasil pekerjaan kelompoknya. Dalam presentasinya perwakilan dari kelompok mempresentasikan cara yang dilakukan oleh peserta didik mengukur keliling dan diameter bibir gelas. Kemudian mempresentasikan hasil masing-masing yang mereka peroleh. Pada saat presentasi juga disampaikan hasil perhitungan perbandingan keliling dengan diameter bibir gelas.

Setelah selesai presentasi oleh peserta didik, peneliti fokus pada jawaban salah satu peserta didik dari kelompok 2. Pada jawaban tersebut, terdapat satu jawaban peserta didik dengan nilai 3,14 . Untuk menyatakan bahwa nilai tersebut merupakan nilai $\pi$, peneliti meminta peserta didik untuk membuka buku bahan ajar yang mereka gunakan. Peserta didik ditugaskan untuk membaca dan mengaitkan anatara angka 3,14 dengan pelajaran yang terdapat pada buku bahan ajar. Dari kegiatan tersebut, ditarik kesimpulan bahwa 3,14 merupakan nilai $\pi$. Nilai $\pi$ diperoleh dari perbandingan keliling dengan diameter lingkaran. Menemukan Rumus Keliling Lingkaran (Pertemuan III)

Untuk membantu peserta didik dalam mengingat pelajaran sebelumnya, peneliti menampilkan hasil pekerjaan peserta didik pada pelajaran sebelumnya. Untuk mengaitkan dengan pelajaran selanjutnya, peneliti menampilkan gambar benda berbentuk lingkaran yang mungkin untuk diukur seperti pertemuan sebelumnya. Setelah melakukan hal tersebut, peneliti menampilkan gambar yang cukup sulit jika harus diukur dengan meteran seperti yang telah dilakukan terhadap gelas. Dalam hal ini gambar yang ditampilkan adalah bundaran Hotel Indonesia (HI). Seiring menampilkan gambar tersebut, guru melakukan diskusi dengan peserta didik. Adapun diskusi yang dilakukan sebagai berikut.

Guru : Jika benda yang berbentuk lingkaran berukuran yang sangat besar, apakah mungkin kita mengukur keliling benda tersebut dengan menggunakan meteran ataupun alat ukur lainnya. 


\section{Jurnal Riset Pendidikan Matematika, 4 (2), 2017 - 134}

N. Nurdiansyah, Rully Charitas Indra Prahmana

Siswa : Mungkin saja pak, tapi tidak menggunakan meteran lagi. Tetapi menggunakan kilometeran.

Guru : Iya, mungkin. Akan tetapi cukup sulit. Apalagi kita harus menemukan kilometeran tadi. Jadi, kira-kira apa yang kita perlukan untuk proses perhitungan keliling lebih mudah?

Siswa : Harus menggunakan rumus, pak.

Diskusi tersebut menyatakan bahwa peserta didik telah menyebutkan bahwa untuk

\begin{tabular}{|c|c|c|c|c|c|}
\hline \multicolumn{3}{|c|}{ uliskan hasil pengukuran gelasmu masing-masing pada tabel berikut! } & \multicolumn{3}{|c|}{ 2. Tuliskan hasil pengukuran gelasmu masing-masing pada tabel berikut! } \\
\hline \multirow{2}{*}{ Gelas } & \multicolumn{2}{|c|}{ Hasil Pengukuran } & \multirow{2}{*}{ Gelas } & \multicolumn{2}{|c|}{ Hasil Pengukuran } \\
\hline & Keliling bibir gelas & Diameter bibir gelas & & \begin{tabular}{|l} 
Keliling bibir gelas \\
\end{tabular} & Diameter bibir gelas \\
\hline I. & 24.5 & 8 & Amanda & $14.2 \mathrm{~cm}$ & $4 \mathrm{~cm}$ \\
\hline 2. & 26.4 & 9.2 & Gian & $26.0 \mathrm{~cm}$ & $8,2 \mathrm{~cm}$ \\
\hline 3 & 28.6 & 9.3 & Nicholas & $26.6 \mathrm{~cm}$ & $8.4 \mathrm{~cm}$ \\
\hline a & 22.5 & 9. 8 & Winny. & $24,7 \mathrm{~cm}$ & $7,1 \mathrm{~cm}$ \\
\hline \multicolumn{3}{|c|}{ iskan hasil pengukuran gelasmu masing-masing pada tabel berikut! } & ...en perngur & tu masung-masung paue & a raver verinut: \\
\hline \multirow{2}{*}{ Gelas } & \multicolumn{2}{|c|}{ Hasil Pengukuran } & Gelas & \multicolumn{2}{|c|}{ Hasil Pengukuran } \\
\hline & \begin{tabular}{|l|} 
Keliling bibir gelas \\
\end{tabular} & Diameter bibir gelas & & Keliling bibir gelas & Diameter bibir gelas \\
\hline Lydia & $23,3 \mathrm{~cm}$ & $7.2 \mathrm{~cm}$ & Jansse. & $2 a \mathrm{~cm}$ & $7.5 \mathrm{~cm}$ \\
\hline Chesta & $21 \mathrm{~cm}$ & $6,5 \mathrm{~cm}$ & Aubrey & $21 . \mathrm{cm}$. & $6.5 \mathrm{~cm}$. \\
\hline Monica & $26,4 \mathrm{~cm}$ & $8 \mathrm{~cm}$ & Karl & $23.6 \mathrm{~cm}$ & $7,4 \mathrm{~cm}$. \\
\hline Vincent & $26.7 \mathrm{~cm}$ & 8,5 an & Eunice & $27.6 \mathrm{~cm}$. & $8.3 \mathrm{~cm}$. \\
\hline
\end{tabular}

Gambar 4. Hasil Pengukuran Keliling dan Diameter Bibir Gelas Setiap Peserta Didik

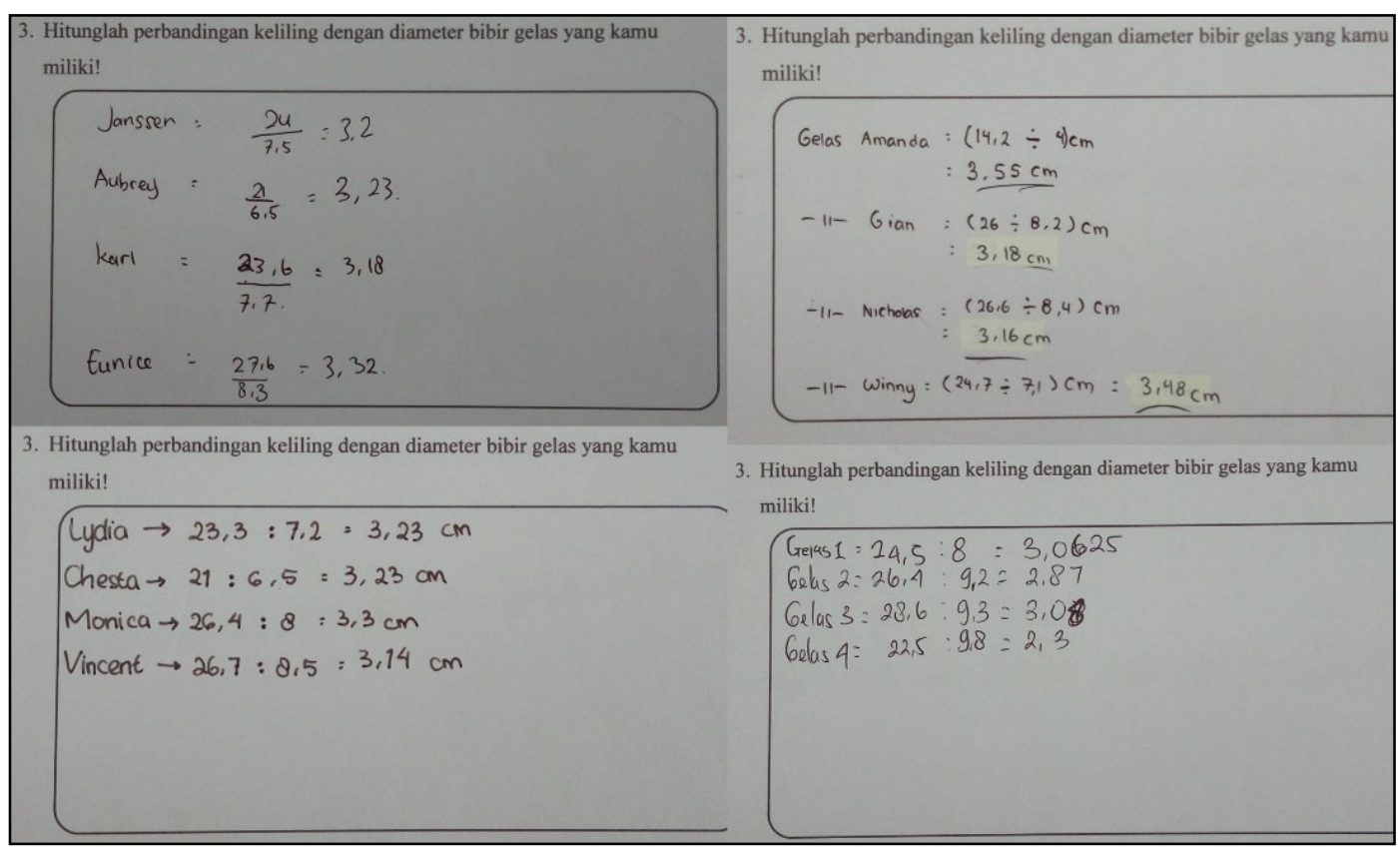

Gambar 5. Hasil Perhitungan Perbandingan Keliling Dengan Diameter Bibir Gelas 
Jurnal Riset Pendidikan Matematika, 4 (2), 2017 - 135

N. Nurdiansyah, Rully Charitas Indra Prahmana

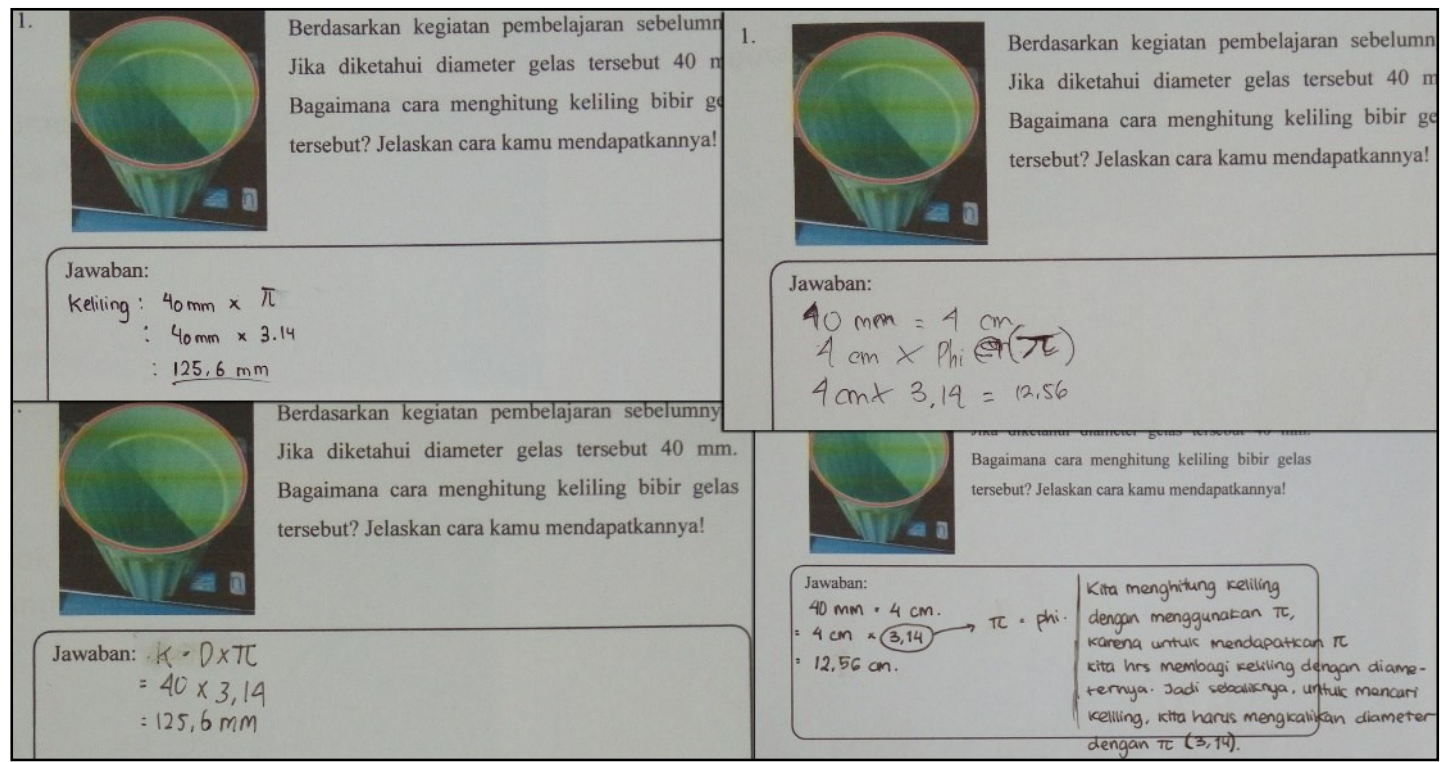

Gambar 6. Hasil Kerja Kelompok Permasalahan Pertama

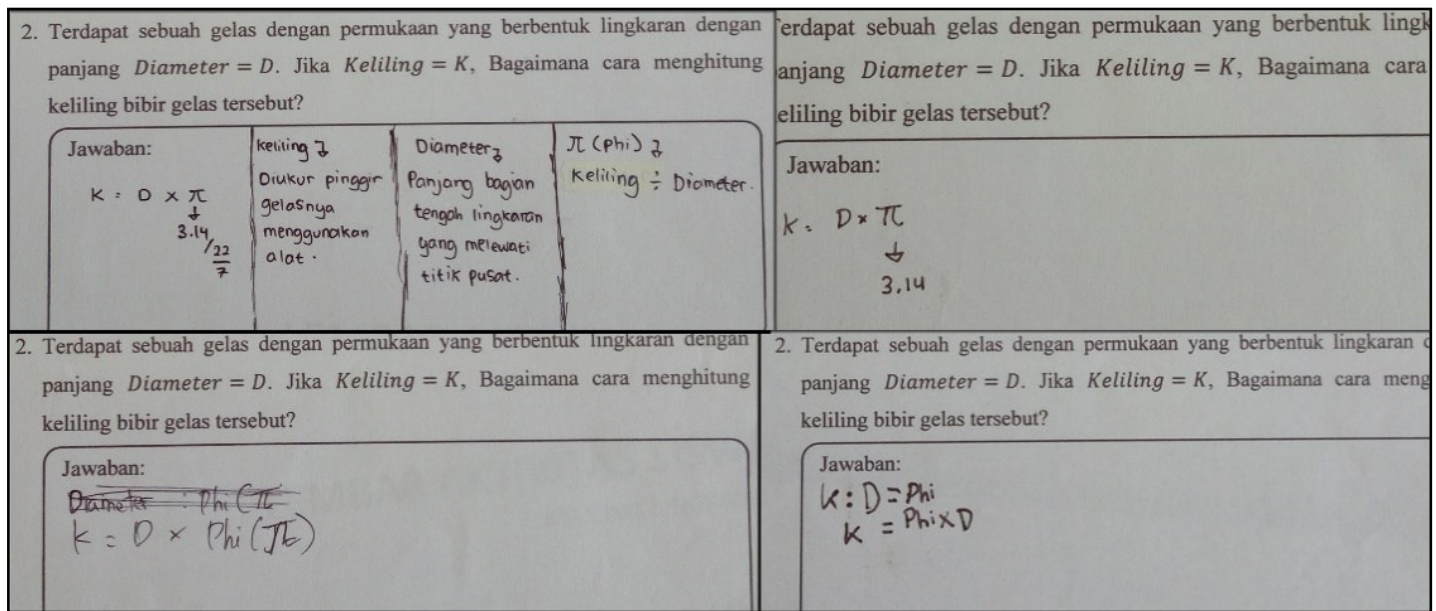

Gambar 7. Hasil Kerja Kelompok Permasalahan Kedua

2. Tuliskan hasil pengukuran gelasmu masing-masing pada tabel berikut!

\begin{tabular}{|c|c|c|}
\hline \multirow{2}{*}{ Gelas } & \multicolumn{3}{|c|}{ Hasil Pengukuran } \\
\cline { 2 - 3 } & Keliling bibir gelas & Diameter bibir gelas \\
\hline Cycia & $23,3 \mathrm{~cm}$ & $7,2 \mathrm{~cm}$ \\
\hline Chesta & $21 \mathrm{~cm}$ & $6,5 \mathrm{~cm}$ \\
\hline Monica & $26,4 \mathrm{~cm}$ & $8 \mathrm{~cm}$ \\
\hline Vincent & $26.7 \mathrm{~cm}$ & $8,5 \mathrm{~cm}$ \\
\hline
\end{tabular}

Gambar 8. Hasil Pengukuran Peserta Didik Yang Cukup Akurat 
Jurnal Riset Pendidikan Matematika, 4 (2), 2017 - 136

N. Nurdiansyah, Rully Charitas Indra Prahmana

3. Hitunglah perbandingan keliling dengan diameter bibir gelas yang kamu miliki!

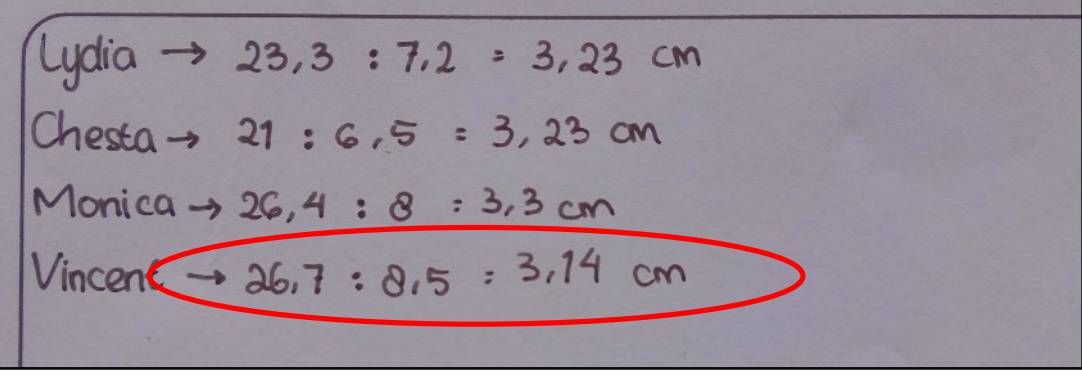

Gambar 9. Hasil Perhitungan Peserta Didik Dengan Nilai 3,14

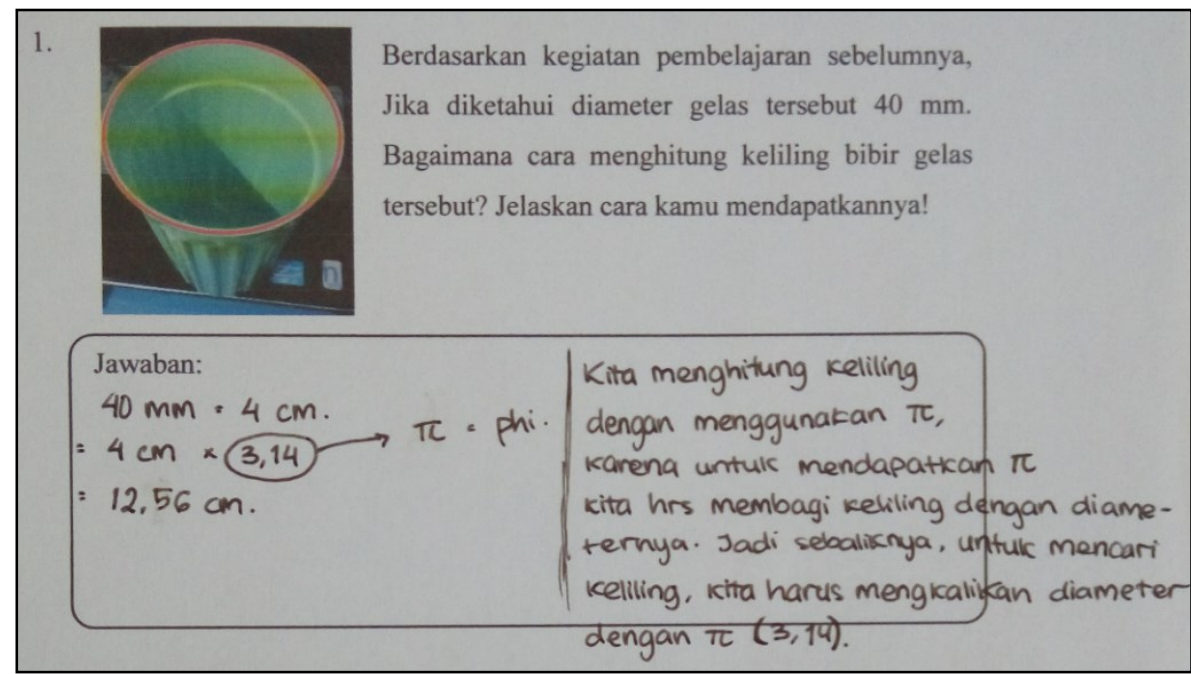

Gambar 10. Hasil Penyelesaian Masalah No.1 pada Pertemuan III

2. Terdapat sebuah gelas dengan permukaan yang berbentuk lingkaran dengan panjang Diameter $=D$. Jika Keliling $=K$, Bagaimana cara menghitung keliling bibir gelas tersebut?

\begin{tabular}{|c|c|c|c|}
\hline Jawaban: & Keliting 7 & Diameter & $\pi(p h i)_{7}$ \\
\hline$K=0 \times \frac{\pi}{f}+\frac{22}{7}$ & $\begin{array}{l}\text { Diukur pinggir } \\
\text { gelasnya } \\
\text { menggunakan } \\
\text { alat. }\end{array}$ & $\begin{array}{l}\text { Panjang bagian } \\
\text { tengah lingkaran } \\
\text { gang melewati } \\
\text { titik pusat. }\end{array}$ & Keliling $\div$ Diameter \\
\hline
\end{tabular}

Gambar 11. Penyelesaian Masalah No.2 pada Pertemuan III

Tabel 1. Hasil Evaluasi Peserta Didik

\begin{tabular}{ccccc}
\hline Nilai Tertinggi & Nilai Terendah & Rata-Rata & Simpangan Baku & Variansi \\
\hline 100 & 36 & 75,38 & 25,07 & 628,26 \\
\hline
\end{tabular}


Sebagian besar kelompok menghitung keliling dari bibir gelas, seperti tampak pada Gambar 6. Padahal yang diminta dalam permasalahan tersebut adalah proses dalam mendapatkan hasil keliling bibir gelas. Berdasarkan kemampuan peserta didik dalam memahami proses dalam mencari keliling tersebut, seharusnya peserta didik dapat mengkonstruksi pengetahuannya untuk menyelesaikan permasalahan kedua. Permasalahan kedua merupakan bentuk umum dari permasalahan pertama. Namun pada penyelesaiannya terdapat beberapa peserta didik yang kurang memahami, sehingga peneliti membantu dengan mengarahkannya melalui pembelajaran yang pernah dipelajari. Dalam hal ini melalui pengetahuan peserta didik dalam pelajaran aljabar (Gambar 7).

\section{Pengisian Soal Evaluasi dan Angket (Pertemuan IV)}

Pada pertemuan ini, kegiatan yang dilakukan adalah pengisian soal evaluasi dan angket respon peserta didik terhadap pembelajaran dengan pendekatan Realistic Mathematics Education (RME). Peserta didik yang hadir pada pertemuan ini sebanyak 13 orang. Angket respon peserta didik diberikan setelah mengerjakan soal evaluasi. Adapun hasil evaluasi 13 peserta didik diperoleh peserta didik terdapat pada Tabel 1.

Hasil pengisian angket respon peserta didik dibagi berdasarkan pernyataan positif dan pernyataan negatif. Perhitungan angket dilakukan berdasarkan skala likert untuk memperoleh persentase dari setiap indikator respon. Dari perhitungan tersebut menunjukkan 59,62\% minat terhadap pelajaran matematika. Menunjukkan $70,50 \%$ kegunaan mempelajari matematika. Menunjukkan 70,75\% minat peserta didik terhadap pembelajaran matematika menggunakan pendekatan Realistic Mathematics Education (RME). Menunjukkan 69,50\% kegunaan mengikuti pembelajaran matematika menggunakan pendekatan Realistic Mathematics Education (RME). Menunjukkan 81,00\% peranan konteks gelas dalam mendukung pembelajaran konsep keliling lingkaran. Rata-rata dari persentase respon tersebut $70,27 \%$ berada pada kategori positif.

\section{Peran Gelas pada Pertemuan I}

Pada penentuan konteks pembelajaran keliling lingkaran, sebagian besar peserta didik memilih gelas yang akan digunakan dalam pembelajaran keliling lingkaran. Namun masih ter- dapat beberapa peserta didik yang beranggapan beberapa benda pada contoh yang diberikan selain gelas juga bisa digunakan. Sebagai contoh, peserta didik masih ada menyebutkan galon bahkan roda mobil. Hal tersebut terjadi karena peserta didik berpikir benda tersebut juga diukur secara manual. Dalam hal seperti ini, peneliti harus memberikan pemahaman seperti yang telah dilakukan pada penelitian. Peneliti memberikan pemahaman bahwa benda yang digunakan dalam pembelajaran selain dekat dengan kehidupan sehari-hari namun juga harus mudah digunakan dalam pembelajaran.

Pada tahap belajar mengukur keliling dan diameter bibir gelas, setiap kelompok melakukan pengukuran terhadap gelas yang mereka miliki. Akan tetapi masih terdapat kelompok yang tidak seluruh anggota melakukan pengukuran. Selain itu, dua gelas berukuran sama yang diberikan kepada setiap kelompok juga membuat peserta didik melakukan pengukuran terhadap satu gelas saja. Dari kejadian tersebut, mengakibatkan tidak seluruh peserta didik melakukan pengukuran dengan baik karena sudah menganggap ukuran gelas 1 sama dengan ukuran gelas lainnya. Namun secara keseluruhan peserta didik cukup mampu melakukan pengukuran keliling dan diameter bibir gelas.

\section{Peran Gelas pada Pertemuan II}

Dari empat kelompok, terdapat satu kelompok yang terdapat hasil pengukuran cukup akurat, yaitu di kelompok 2. Adapun hasil yang diperoleh dari kelompok tersebut dapat dilihat pada Gambar 8.

Jika diperhatikan nilai keliling dan diameter bibir gelas yang dilingkari dengan warna merah tersebut, nilai itulah yang cukup presisi dalam melakukan pengukurannya. Setelah dilakukan perhitungan, nilai perbandingan keliling dengan diameter bibir gelas tersebut adalah 3,14117647 ... dibulatkan ke 3,14. Hasil perhitungan peserta didik dapat dilihat pada Gambar 9.

Hasil yang diperoleh peserta didik di atas menunjukkan terdapat satu peserta didik yang melakukan pengukuran cukup teliti. Dari pengukuran yang cukup teliti tersebut, setelah perhitungan mendapat sebuah nilai yaitu 3,14 . Dari 17 peserta didik yang melakukan pengukuran, hanya terdapat satu peserta didik yang mendapatkan hasil 3,14..., hal ini disebabkan pada saat pengukuran keliling dan diameter bibir gelas kurang teliti. Ada beberapa peserta didik yang cenderung membulatkan hasil pengukuran 
Jurnal Riset Pendidikan Matematika, 4 (2), 2017 - 138

N. Nurdiansyah, Rully Charitas Indra Prahmana

yang diperoleh. Padahal ukuran sesungguhnya itu merupakan hasil yang cukup baik untuk mendapat nilai $\pi$.

\section{Peran Gelas pada Pertemuan III}

Terdapat satu kelompok yang dapat menyelesaikan masalah yang terdapat pada LAPD. Adapaun hasil yang diperoleh dari kelompok tersebut dapat dilihat pada Gambar 10. Dari Gambar 10 terlihat bahwa peserta didik cukup mampu dalam menemukan cara untuk menghitung keliling lingkaran. Namun akan sulit bagi peserta didik jika informasi yang diberikan dalam bentuk umum. Hal ini terlihat pada penyelesaian masalah yang terdapat di LAPD. Hasil tersebut terlihat pada Gambar 11. Berdasarkan hasil penyelesaian masalah tersebut dapat dilihat bahwa peserta didik sudah menemukan cara menghitung keliling bibir gelas. Namun, pada penjelasannya peserta didik kurang tepat hingga mencapat hasilnya $K=D \times \pi$. Kekurangan tersebut diakibatkan peserta didik tidak bisa menjelaskan dalam menjelaskan pemikirannya secara tertulis.

\section{Pengisian Soal Evaluasi dan Angket (Pertemuan IV)}

Dari hasil penelitian pada pertemuan IV, terdapat peserta didik yang mendapat nilai tertinggi 100 dan nilai terendah 20. Nilai tersebut menunjukkan terdapat peserta didik yang paham dan masih terdapat peserta didik yang kurang paham terhadap pembelajaran yang diberikan. Berdasarkan angket yang diisi oleh peserta didik, persentase minat peserta didik terhadap pembelajaran matematika adalah $59,62 \%$ dengan kategori netral. Dari hasil tersebut berarti terdapat peserta didik yang tidak memberikan pernyataan terhadap minat pada pembelajaran matematika, sehingga hal tersebut dapat mengakibatkan rendahnya skor yang diperoleh pada pembelajaran matematika.

Hasil evaluasi pembelajaran juga dilihat berdasarkan pengisian angket oleh peserta didik. Pernyataan positif menyatakan bahwa peserta didik sangat setuju bahwa pembelajaran matematika dengan pendekatan RME melatih untuk berdiskusi dalam menyampaikan ide-ide terkait dengan masalah yang diberikan. Sedangkan dari pernyataan negatif, peserta didik tidak merasa kesulitan mengerjakan permasalahan yang diberikan dengan pendekatan RME. Dari kedua pernyataan tersebut berarti pembelajaran matematika dengan pendekatan RME melatih peserta didik berdiskusi, sehingga dari latihan tersebut mengakibatkan peserta didik merasa tidak kesulitan dalam menyelesaikan permasalahan yang diberikan.

Selain berdasarkan jumlah skor dari setiap pernyataan tersebut, dari hasil perhitungan dengan menggunakan skala likert menyatakan bahwa minat peserta didik terhadap pelajaran matematika dengan kategori netral. Respon peserta didik terhadap kegunaan mempelajari matematika berada pada kategori positif. Minat peserta didik terhadap pembelajaran matematika menggunakan pendekatan RME memiliki respon dengan kategori positif. Kegunaan mengikuti pembelajaran matematika menggunakan pendekatan RME mendapat respon yang positif dari peserta didik. Peserta didik merespon sangat positif terhadap peranan konteks gelas dalam mendukung pembelajaran konsep keliling lingkaran. Hasil tersebut sejalan dengan penelitian yang dilakukan oleh Usdiyana, Purniati, Yulianti, \& Harningsih (2009), yaitu pada umumnya peserta didik merasa senang, tertarik, dan mudah mengerti mempelajari matematika dengan pendekatan realistik.

Secara keseluruhan, berdasarkan hasil pengisian soal evaluasi, rata-rata skor evaluasi peserta didik lebih dari nilai Kriteria Ketuntasan Minimal (KKM) di Sekolah Menengah Pertama (SMP) Surya Bangsa Tangerang. Rata-rata skor evaluasi peserta didik 75,38, sedangkan KKM sekolah tersebut 65,00. Berdasarkan hasil angket yang diperoleh, rata-rata persentase respon peserta didik terhadap peran konteks gelas dalam mendukung pembelajaran konsep keliling lingkaran adalah $81 \%$ dengan kategori sangat positif.

\section{SIMPULAN}

Konteks gelas berperan dalam mendukung pembelajaran konsep keliling lingkaran. Hal tersebut dapat dilihat berdasarkan skor ratarata yang diperoleh peserta didik lebih dari Kriteria Ketuntasan Minimal (KKM) Sekolah Menengah Pertama (SMP) Surya Bangsa Tangerang tahun ajaran 2015/2016 semester II, yaitu 75,38. Selain itu, hasil pengisian angket menunjukkan bahwa respon peserta didik terhadap peran konteks gelas sangat positif. Selanjutnya, sebagian besar peserta didik memiliki respon yang positif terhadap pembelajaran matematika dengan pendekatan RME. Pernyataan tersebut diperoleh dari hasil angket yang menunjukkan bahwa persentase respon peserta didik terhadap pembelajaran matematika menggunakan pendekatan Realistic Mathematics 


\section{Jurnal Riset Pendidikan Matematika, 4 (2), 2017 - 139}

N. Nurdiansyah, Rully Charitas Indra Prahmana

Education (RME) adalah 70,75\% dengan kategori positif.

Berdasarkan kesimpulan tersebut peneliti menyarankan agar para guru dapat menggunakan berbagai konteks yang dekat dengan siswa dalam membelajarkan konsep matematika, salah satunya yaitu pemanfaatan konteks gelas dalam pembelajaran keliling lingkaran. Selain itu, terkait penelitian selanjutnya hendaknya dilakukan penelitian mengenai konteks-konteks lain dalam pembelajaran matematika, sehingga pembelajaran menjadi lebih bermakna dan mampu mengangkat prestasi belajar siswa.

\section{DAFTAR PUSTAKA}

Ahmad, A., Usodo, B., \& Riyadi, R. (2014). Eksperimentasi model pembelajaran kooperatif tipe group investigation (GI) dan jigsaw II pada materi pokok bangun ruang ditinjau dari kemampuan spasial siswa kelas VIII SMP Negeri seKabupaten Karanganyar tahun pelajaran 2013/2014. Jurnal Elektronik Pembelajaran Matematika, 2(8), 804$815 . \quad$ Retrieved from http://jurnal.fkip.uns.ac.id/index.php/s2m ath/article/view/4821

Emilya, D., Darmawijoyo, D., \& Ilma, R. (2010). Pengembangan soal-soal openended materi lingkaran untuk meningkatkan penalaran matematika siswa kelas VIII Sekolah Menengah Pertama Negeri 10 Palembang. Jurnal Pendidikan Matematika, 4(2). Retrieved from

http://ejournal.unsri.ac.id/index.php/jpm/a rticle/view/316

Gravemeijer, K. P. E. (1994). Developing realistic mathematics education: Ontwikkelen van Realistisch Reken/wiskundeonderwijs. Utrecht: CD[beta] Press.

Hadi, S. (2017). Pendidikan matematika realistik: Teori, pengembangan dan implementasinya. Jakarta: Rajawali Pers.

Hernawati, F. (2016). Pengembangan perangkat pembelajaran matematika dengan pendekatan PMRI berorientasi pada kemampuan representasi matematis. Jurnal Riset Pendidikan Matematika, 3(1), 34-44. https://doi.org/10.21831/jrpm.v3i1.9685

Menteri Pendidikan Nasional Republik Indonesia. Peraturan Menteri Pendidikan
Nasional Republik Indonesia Nomor 22 Tahun 2006 tentang standar isi untuk satuan pendidikan dasar dan menengah, Pub. L. No. 22 (2006). Indonesia.

Miles, M. B., \& Huberman, A. M. (1994). Qualitative data analysis: An expanded sourcebook. London: SAGE Publications Ltd.

Moleong, L. J. (2013). Metodologi penelitian kualitatif (Ed. Rev.). Bandung: PT Remaja Rosdakarya.

Prahmana, R. C. I. (2010). Permainan "Tepuk Bergilir" yang berorientasi konstruktivisme dalam pembelajaran. Jurnal Pendidikan Matematika, 4(2). Retrieved from http://ejournal.unsri.ac.id/index.php/jpm/a rticle/view/406

Prahmana, R. C. I. (2012, January 17). Pendesainan pembelajaran operasi bilangan menggunakan permainan tradisional tepuk bergambar untuk siswa kelas III sekolah dasar (SD). Univesitas Sriwijaya.

https://doi.org/10.13140/RG.2.2.33884.59 529

Prahmana, R. C. I., Zulkardi, Z., \& Hartono, Y. (2012). Learning multiplication using indonesian traditional game in third grade. Journal on Mathematics Education, 3(2). Retrieved from http://ejournal.unsri.ac.id/index.php/jme/a rticle/view/570

Santosa, B., Budiyono, B., \& Subanti, S. (2014). Eksperimentasi model pembelajaran team games tournament (TGT) dan jigsaw dengan pendekatan matematika realistik ditinjau dari kecemasan menghadapi tes siswa kelas VII SMP Kabupaten Brebes tahun pelajaran 2012/2013. Jurnal Elektronik Pembelajaran Matematika, 2(1), 88-98. Retrieved from http://jurnal.fkip.uns.ac.id/index.php/s2m ath/article/view/3656

Sari, W. R. (2016). Pengembangan perangkat pembelajaran bangun ruang di SMP dengan pendekatan pendidikan matematika realistik. Jurnal Riset Pendidikan Matematika, 3(1), 109. https://doi.org/10.21831/jrpm.v3i1.10407

Usdiyana, D., Purniati, T., Yulianti, K., \& Harningsih, E. (2009). Meningkatkan kemampuan berpikir logis siswa SMP 


\section{Jurnal Riset Pendidikan Matematika, 4 (2), 2017 - 140}

N. Nurdiansyah, Rully Charitas Indra Prahmana

melalui pembelajaran matematika realistik. Jurnal Pengajaran MIPA, 13(1), $1-14$.

Wibowo, A. (2017). Pengaruh pendekatan pembelajaran matematika realistik dan saintifik terhadap prestasi belajar, kemampuan penalaran matematis dan minat belajar. Jurnal Riset Pendidikan

Matematika, 4(1), 1.

https://doi.org/10.21831/jrpm.v4i1.10066

Wijaya, A. (2012). Pendidikan matematika realistik: Suatu alternatif pendekatan pembelajaran matematika. Yogyakarta: Graha Ilmu. 